\title{
Health indicators
}

England and Wales

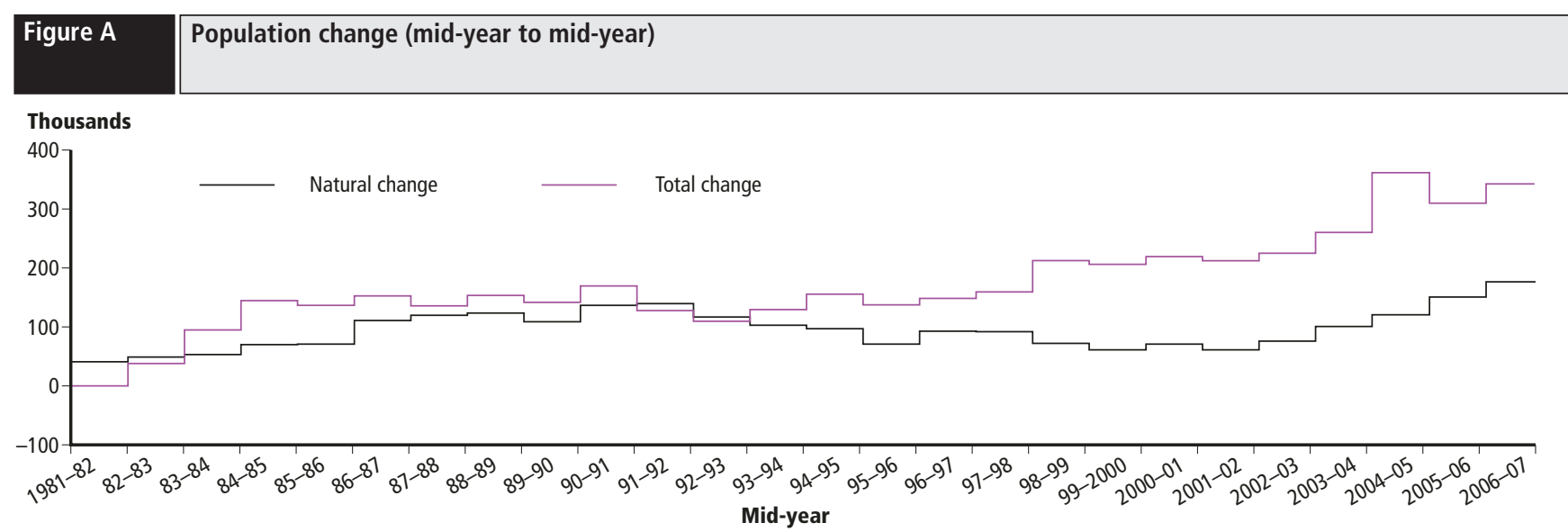

\section{Figure B}

Age-standardised mortality rate ${ }^{1}$

\section{Rate per million population}

20,000

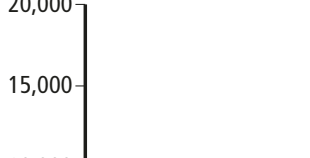

10,000

5,000

0

1981

1983

1985

1987

1989

1991

993 Year

\section{Figure C}

Infant mortality (under 1 year)

Rate per thousand live births

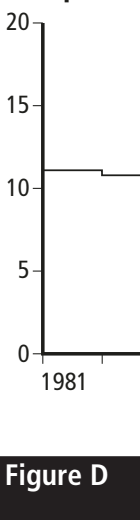

Age-standardised rate per thousand women 15-44

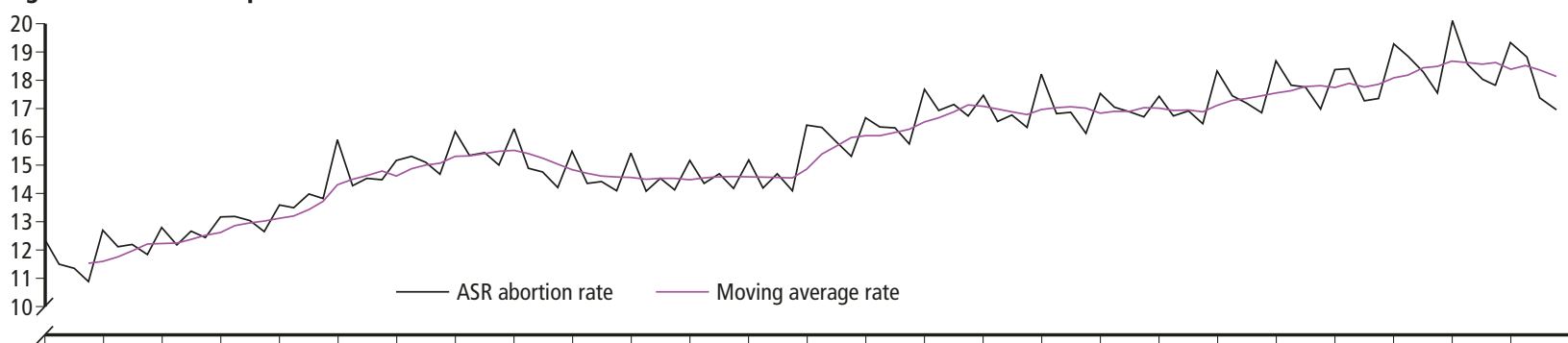

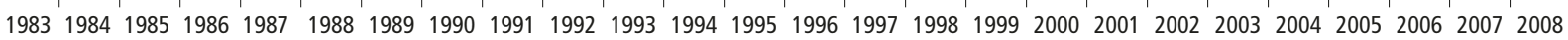

1 The age-standardised mortality rate for 2007 is based on mid-2007 population estimates published on 21 August 2007. 